\title{
Liver Injury From Tumor Necrosis Factor- $\alpha$ Antagonists: Analysis of Thirty-four Cases
}

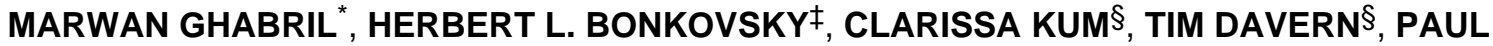 \\ H. HAYASHI", DAVID E. KLEINER ${ }^{\Uparrow}$, JOSE SERRANOף, JIM ROCHON", ROBERT J. \\ FONTANA $^{\star *}$, and MAURIZIO BONACINI§ for the U.S. Drug-Induced Liver Injury Network
}

*Department of Medicine, Indiana University School of Medicine, Indianapolis, Indiana ${ }^{*}$ Cannon Research Center, Department of Internal Medicine, and Liver-Biliary-Pancreatic Center, Carolinas Medical Center, Charlotte, North Carolina §Department of Transplantation, California Pacific Medical Center, San Francisco, California IDepartment of Internal Medicine, University of North Carolina at Chapel Hill, Chapel Hill, North Carolina ILiver Disease Research Branch, National Institute of Diabetes and Digestive and Kidney Diseases, National Institutes of Health, Bethesda, Maryland \#Duke Clinical Research Institute, Durham, North Carolina ${ }^{* *}$ Department of Internal Medicine, University of Michigan Medical Center, Ann Arbor, Michigan

\section{Abstract}

BACKGROUND \& AIMS-Tumor necrosis factor (TNF)- $\alpha$ antagonists have been associated with drug-induced liver injury (DILI). We reviewed cases of DILI in the United States to identify those associated with use of TNF- $a$ antagonists.

\begin{abstract}
METHODS-We searched the U.S. DILI Network (DILIN) database, from 2003 to 2011, for cases associated with TNF- $\alpha$ antagonists. Mean Roussel-Uclaf Causality Assessment Method scores were calculated. A DILIN severity score was assigned according to a previously published scale, and we identified 6 subjects likely to have DILI associated with use of TNF- $\alpha$ antagonists. We also searched PubMed for articles that reported hepatotoxicity from TNF- $a$ antagonists, identifying 28 additional cases suitable for analysis.

RESULTS-The drugs presumed to have caused DILI were infliximab $(\mathrm{n}=26)$, etanercept $(\mathrm{n}=$ $4)$, and adalimumab $(\mathrm{n}=4)$. The anti-TNF- $a$ agent was the probable cause of 12 cases of DILI (35\%), a very likely cause for $21(62 \%)$, and a definite cause for $1(3 \%)$. Median latency was 13 weeks (range, 2-104); however, 7 cases (20\%) had latency periods longer than 24 weeks. Twentytwo of 33 subjects who underwent serologic analysis (67\%) tested positive for anti-nuclear and/or smooth muscle antibodies. Of these 22, 17 underwent liver biopsy; 15 subjects had clear features of autoimmunity. The 22 subjects with autoimmune features had longer median latency (16 vs 10 weeks) and higher peak levels of alanine aminotransferase (784 vs $528 \mathrm{U} / \mathrm{L}$ ) than the 12 without such features. There was 1 case of severe cholestasis. All but one subject improved after discontinuation of the implicated drug; 12 subjects received corticosteroid therapy. No deaths
\end{abstract}

\footnotetext{
(C) 2013 by the AGA Institute

Address requests for reprints to: Maurizio Bonacini, MD, Department of Medicine, California Pacific Medical Center, 1580 Valencia Street, Suite 804, San Francisco, California 94110. bonacim@sutterhealth.org; fax: (415) 392-5632.

Supplementary Material

Note: To access the supplementary material accompanying this article, visit the online version of Clinical Gastroenterology and Hepatology at www.cghjournal.org, and at doi:10.1016/j.cgh.2012.12.025.

Conflicts of interest

The authors disclose no conflicts.
} 
were attributed to liver injury, although one patient with preexistent cirrhosis required liver transplantation.

CONCLUSIONS-Acute liver injury caused by TNF- $\alpha$ antagonists may be a class effect because multiple agents in this category have been implicated. The most common presentation is an autoimmune phenotype with marked hepatocellular injury, but a mixed non-autoimmune pattern or predominant cholestasis also occurs. The prognosis is usually good after drug discontinuation, although some patients may benefit from a course of corticosteroids. ClinicalTrials.gov: Number, NCT00345930

\section{Keywords}

Drug-Induced Liver Injury; Tumor Necrosis Factor; TNF- $a$ Antagonists; Hepatotoxicity; Autoimmunity

Biological response modifiers are prescribed to modify the body's response to inflammation, infection, and neoplasia. These compounds include interferons, interleukins, bone marrow colony-stimulating factors, and tumor necrosis factor (TNF) $-\alpha$ antagonists. All of the TNF$a$ antagonists have been associated with drug-induced liver injury (DILI). ${ }^{1,2}$ In addition, these agents carry specific warnings about the risk of reactivation of chronic hepatitis B. ${ }^{3}$

A Food and Drug Administration postmarketing surveillance program received more than 130 reports of liver injury resulting from either infliximab or etanercept treatment. ${ }^{4}$ The results were reported in Food and Drug Administration minutes, and although in many of these cases competing causes were identified, including viral reactivation, 7 of the reported cases were notable for their strong association with the TNF- $a$ antagonist in question. ${ }^{4}$

Two cases of successful treatment with etanercept after a prior DILI episode attributed to infliximab have recently been reported, suggesting that cross-toxicity is not universal among the different TNF- $\alpha$ antagonists. ${ }^{5,6}$ However, it has been shown that several TNF- $a$ antagonists have a similar ability to elicit the development of serologic markers of autoimmunity. These compounds have also been associated with reactivation of latent tuberculosis, hepatitis B, the development of lymphoma, demyelinating disease, seizures, aplastic anemia, and skin rash. ${ }^{3}$ Accordingly, some reported cases of TNF- $\alpha$ antagonistinduced liver injury exhibited autoimmune features on liver histology. ${ }^{6}$ This suggests the possibility that genetically susceptible individuals may generate an idiosyncratic immune response after inhibition of the TNF- $a$ pathway. ${ }^{1}$

In this report, we describe cases that are deemed to be $250 \%$ likely to represent bona fide TNF- $a$ antagonist-associated hepatotoxicity. Six were enrolled in the ongoing U.S. DrugInduced Liver Injury Network (DILIN) Prospective Registry Study. ${ }^{7}$ We also performed a detailed literature search and critically reviewed 34 additional published cases. Of those, 28 met criteria for inclusion. Herein we summarize the clinical and laboratory presentation as well as clinical outcome of these 34 subjects.

\section{Methods}

We searched the U.S. DILIN database (between 2003 and 2011) for instances of DILI associated with TNF- $\alpha$ antagonists that were scored probable (score 3) or higher likelihood on the following scale developed by the DILIN group: $1=$ definite $(>95 \%$ likelihood), $2=$ highly likely $(76 \%-95 \%), 3=$ probable $(51 \%-75 \%), 4=$ possible $(25 \%-50 \%)$, and $5=$ unlikely $(<25 \%) .{ }^{7}$ This means that we did not include cases of elevated liver test results associated with a TNF-alpha antagonist, which by consensus evaluation were found to be only possible or unlikely (ie, $\mathbf{5 0 \%}$ likelihood of DILI). The Roussel-Uclaf Causality 
Assessment Method (RUCAM) ${ }^{8}$ score was calculated according to published guidelines, and the mean score (from 3 reviewers) was calculated. Causality assessment by RUCAM scores is as follows: 0 or lower, relationship with the drug excluded; $1-2$, unlikely; $3-5$, possible; $6-8$, probable; and $>8$, highly probable. A DILIN severity score was assigned according to a previously published scale from 1 (mild with bilirubin $<2.5 \mathrm{mg} \%$ ) to 5 (death or liver transplantation). ${ }^{7}$ Six subjects with a causality score of 1,2 , or 3 were identified, and demographics and descriptive statistics for them were summarized by the Duke Clinical Research Institute, the data coordinating center of the DILIN.

The authors had access to the study data and have reviewed and approved the final manuscript.

\section{Search and Review of Literature}

A detailed literature review was performed by using the PubMed database in April 2011 by using the search terms "hepatotoxicity," "liver injury," "tumor necrosis factor," and the generic names of all commercially available TNF- $a$ antagonists. All cases that were published as of December 2011 were reviewed by 2 of the authors by using a causality assessment method similar to that used in the DILIN Causality Committee meetings. However, instead of 1 principal investigator and 2 reviewers (not involved in the care of the subject), we used 2 DILIN reviewers (M.G., M.B.) who discussed the published cases, with assistance of a third reviewer (H.L.B.) in case of lack of consensus. However, the 2 reviewers came to a consensus in all literature cases and assigned each published case both a causality and a severity score in a fashion similar to and according to the DILIN protocol. ${ }^{1,2}$ Only those cases that were deemed at least a probable (score 3 or lower) on the DILIN causality scale were included in this report. Six published cases were excluded from the analysis because they were scored as only possible; thus, 28 cases are included in this report. $^{9-13}$

Autoimmunity was defined by the presence of antinuclear antibody (ANA) or smooth muscle antibody in a titer $\geq 1 / 80$ (at the time of DILI onset) or, if available, liver histology consistent with autoimmune hepatitis (AIH). Liver biopsies obtained from the subjects in the DILIN registry were all interpreted by D.E.K. without knowledge of clinical or laboratory features.

\section{Results}

\section{Drug-Induced Liver Injury Network Subjects}

Selected demographic, clinical, and serum biochemical features of the 6 DILIN subjects with hepatotoxicity attributed to TNF- $\alpha$ antagonists are shown in Table 1 . The median latency (duration of drug use before onset) was 16 weeks (range, 2-52 weeks). At presentation, half had jaundice, half had nausea, but only one had fever, and none had immunoallergic features of skin rash or eosinophilia. The hepatic injury pattern was predominantly hepatocellular; 4 patients developed jaundice, but only 1 had significantly impaired coagulation (international normalized ratio [INR], 3.5), and none developed ascites or other signs of hepatic failure. Five of the 6 patients were treated with corticosteroids. One patient had a protracted illness, but all ultimately recovered and could be withdrawn from corticosteroid therapy without recurrence. Clinical summary of a representative DILIN case is reported below, and those of the remaining cases are included in the Supplementary Materials. 


\section{Drug-Induced Liver Injury Network case report}

Subject 1-A 28-year-old man with quiescent Crohn's disease was started on infliximab (300 mg [5 mg/kg] intravenously monthly) for ankylosing spondylitis refractory to celecoxib. Four months before starting infliximab, serum enzymes were normal. Concomitant medications included fluoxetine, fluticasone, and omeprazole, and he reported no known drug allergies. After the fourth infusion, alanine aminotransferase (ALT) levels increased to $132 \mathrm{U} / \mathrm{L}$, and total bilirubin was $0.8 \mathrm{mg} / \mathrm{dL}$. In the week of his fifth infusion, ALT increased to $311 \mathrm{U} / \mathrm{L}$, whereas alkaline phosphatase (Alk Phos) and bilirubin remained normal. Infliximab was stopped. He remained asymptomatic throughout, but ALT peaked at 1270 U/L. Serum ANA was initially negative, but 1 month later, it was positive in a titer of 1:160. Anti-smooth muscle antibody (ASMA) remained negative, and immunoglobulin (Ig) G levels were normal. Serum ALT fell to $198 \mathrm{U} / \mathrm{L}$ by 2 months after the last infusion but rose again to $1167 \mathrm{U} / \mathrm{L}$, with a total bilirubin of $2.0 \mathrm{mg} / \mathrm{dL}$ (Figure $1 \mathrm{Al}$ ). Evaluation for hepatitis $\mathrm{A}, \mathrm{B}$, and $\mathrm{C}$ was negative, and hepatic computed tomography and ultrasound were normal. A liver biopsy obtained 3 months after the last infliximab infusion showed portal and lobular mixed inflammatory infiltrate with autoimmune features and no fibrosis (Figure $1 A 2$ and $A 3)$. Prednisone (50 mg/d) was started, and liver enzymes fell into the normal range within 2 months. Prednisone was tapered and stopped after 7 months. The serum ANA reverted to negative. He was placed on etanercept 11 months after his last dose of infliximab, and serum enzymes remained normal. The assigned DILIN causality score was 1 (definite), RUCAM 5 (possible), and severity score 1 (mild).

Comment-This subject developed progressively elevated serum aminotransferase levels after 5 doses of infliximab, but he remained asymptomatic and had only a mild increase in serum bilirubin. He was taking fluoxetine, fluticasone, and omeprazole at the time of onset, but these agents had been taken for more than a year and were continued. No other cause of liver disease was identified. Liver biopsy findings, ANA positivity, and response to prednisone suggested DILI with auto-immune features triggered by infliximab.

\section{Literature Review}

Twenty-eight additional published cases were evaluated, and the results are summarized together with the 6 DILIN cases in Tables 2 and 3. The most common underlying disease was psoriasis and/or psoriatic arthritis (13 cases, 8 women), followed by inflammatory bowel disease (12 cases, 7 women), rheumatoid arthritis (6 cases, all women), and ankylosing spondylitis ( 3 cases, 1 woman). The drug most commonly incriminated was infliximab ( 26 cases), followed by etanercept and adalimumab (4 each). No published cases were found linked to natalizumab, golimumab, or certolizumab. On the basis of the reports and causality assessment by 2 of the authors (M.G. and M.B.), 1 case was considered definite, 21 were considered very likely (causality score 2), and 12 cases were deemed probable (causality score 3 ). An alcohol use history was available in 21 cases. Alcohol was considered a possible competing cause in 3 cases, but the final causality assessment for the anti-TNF compound was very likely in 1 case and probable in the other 2 .

Severity scores could be ascertained in 30 cases, and the reaction was rated as mild in 20, moderate in 8, and severe (including 1 liver transplant) in 2. Peak serum ALT ranged from 140-2250 U/L, and bilirubin ranged from normal-27.7 mg/dL. The presence or absence of autoimmune serologies or histologic features was reported in 33 cases; 22 (66\%) had autoimmune serologic markers and/or histologic features at some point during the clinical course. Overall, the prognosis was good, although 1 patient with underlying cirrhosis required liver transplantation. ${ }^{14}$ Twelve subjects improved after discontinuation of the implicated drug and with the addition or increased dosage of oral or parenteral corticosteroid therapy. The remainder improved after discontinuation of the implicated drug. Several 
patients tolerated treatment with etanercept without recurrence of liver injury after cessation of infliximab or adalimumab. $5,6,9,15,16$ Two did well with low-dose etanercept after DILI associated with full dose. ${ }^{11,12}$

We compared 22 cases with autoimmune features (serology and/or histology) vs those without (Table 4). Those with auto-immune features had serum ANA titers ranging from 1:80 to 1:2560, and 17 subjects underwent liver biopsy that revealed autoimmune histopathologic features in 15. In contrast, among the 8 (of 12) patients without positive autoimmune serologies who underwent liver biopsy, none had clear-cut autoimmune features. Patients with autoimmune features tended to have longer latency and were more likely to have a hepatocellular pattern of serum enzyme elevations, with higher peak ALT and higher $R$ values (Table 4).

\section{Discussion}

Increased levels of TNF- $a$ have been described in numerous inflammatory and infectious conditions, including liver diseases, eg, alcoholic hepatitis. As a result, anti-TNF- $a$ antibodies or other antagonists have been proposed as therapies for such liver diseases, because uncontrolled pilot studies have suggested beneficial effects. ${ }^{17,18}$ However, randomized, controlled trials have indicated that persons with alcoholic hepatitis treated with infliximab fared worse than untreated controls. ${ }^{17,18}$ Because TNF- $a$ has beneficial as well as deleterious effects, down-regulation of its levels or activity needs to be carefully considered. In some patients treated with TNF- $a$ blockers, acute liver injury has developed that may be severe and prolonged. ${ }^{2}$ Of the TNF- $a$ antagonists, infliximab-associated injury has been the best documented, most likely because of its earlier approval and more widespread clinical use. As of 2011, more than 1,500,000 persons had been exposed to infliximab alone. ${ }^{1,2}$ Fewer bona fide etanercept-induced hepatotoxicity case reports have been published. In fact, this drug has been successfully used after resolution of DILI caused by other TNF- $a$ inhibitors $5,6,9,15,16$ (and DILIN subject 8). In all, a switch to an alternative TNF- $\alpha$ antagonist because of predominantly infliximab-associated DILI did not result in recurrent liver injury in 5 published cases. ${ }^{5,6,15,19,20}$

A recent review of a national database reported that the risk of elevation of liver enzymes in patients with rheumatoid arthritis who were on TNF- $a$ antagonists was low (ALT or aspartate aminotransferase [AST] elevation $>3 \times$ upper limit of normal $<1 \%$ ) and that etanercept was less likely to be associated with liver enzyme elevation as compared with infliximab or adalimumab. ${ }^{21}$ The fact that so few cases have been attributed to etanercept in psoriatic disease may be due to its more recent approval in 2004 and the smaller number of patients treated. Certolizumab (Cimzia) and golimumab (Symponi) are the newest drugs in the class. To our knowledge, DILI attributed to these 2 agents has not yet been reported, although both package inserts mention the risk of hepatitis B virus reactivation as well as idiosyncratic elevation of ALT, which are greater than in placebo. A systematic review of the use on anti-TNF agents in patients with chronic hepatitis $C$ confirms the general impression that these agents are safe in the majority of patients, including those with underlying liver disease. ${ }^{22}$ An exception is that these agents can cause reactivation of hepatitis B.,22

Infliximab, etanercept, and adalimumab inhibit TNF- $a$ signaling by directly binding soluble and membrane-bound TNF- $a$, and all contain, at least in part, a human IgG antibody component. Nevertheless, they differ in their molecular structures. Infliximab is a chimeric IgG1 monoclonal antibody, whereas etanercept is a fusion of recombinant soluble TNF- $a$ receptor type 2 with an $\mathrm{Fc}$ domain of human $\mathrm{IgG1}$, and adalimubab is a fully humanized IgG1 monoclonal antibody. In view of these differences, it is not surprising that in a few 
cases, a lack of cross-toxicity between etanercept and infliximab has been noted. ${ }^{16,23}$ Each of these subjects had developed liver toxicity while using infliximab, recovered after cessation of infliximab, and did not exhibit any relapse in liver injury when later treated with etanercept. A similar case report has also recently been published that demonstrated successful treatment of psoriatic arthritis with etanercept after adalimumab hepatotoxicity. ${ }^{15}$ In addition, infliximab and etanercept have also been observed to elicit different effects on the humoral autoimmune response. ${ }^{24}$ The frequent development of autoantibodies within 1 year of treatment has been reported in infliximab-treated patients, whereas in etanercepttreated patients, no significant variation of ANA or anti-DNA level was observed. ${ }^{25} \mathrm{In}$ contrast, all 4 etanercept cases in this report (2 from DILIN) developed serologic autoimmune markers, with ANA titers as high as 1:1280 and weakly positive serum antimitochondrial antibody in 1 case (Tables 2 and 3).

We used a causality assessment method similar to that used in the DILIN causality committee meetings, with 2 reviewers (M.G., M.B.) who discussed the published cases and came to a consensus. According to this process, 22 of 34 subjects $(65 \%)$ were deemed definite or very likely and $12(35 \%)$ probable.

Clinically, the most common presentation of anti-TNF hepatotoxicity is an acute hepatocellular injury ( $R>5$ in $75 \%$ of cases), occurring a median of 13 weeks after initiation of therapy; however, 7 of 34 cases had a latency greater than 6 months. Pure bland cholestasis was also observed in 1 case (DILIN subject 3). Laboratory data revealed that serum aminotransferases ranged from 140 to $>2000 \mathrm{U} / \mathrm{L}$ and that bilirubin was significantly elevated ( $>3 \mathrm{mg} / \mathrm{dL})$ in 10 of 27 patients $(37 \%)$. Of note, reactivation of chronic hepatitis B, acute hepatitis B virus, hepatitis $C$ virus, and hepatitis $E$ virus infection were excluded in all of the DILIN cases. Autoimmune features (positive ANA and/or ASMA) were common, including some with classic histologic features of AIH. ${ }^{6,9,26-33}$

Fortunately, the prognosis was usually good. The fact that in 6 cases ( 3 very likely and 3 probable), the autoantibodies decreased or disappeared with corticosteroid therapy suggests drug-induced rather than de novo idiopathic autoimmunity. ${ }^{34}$ This autoimmune signature (either AIH on biopsy or ANA titers $\geq 1: 80$ ) was seen in 22 patients and occurred with infliximab, adalimumab, and etanercept treatment, supporting the concept that despite molecular structural differences, a class effect is present. The 12 cases lacking autoimmune features were also different, because their latency was significantly shorter (10 vs 16 weeks), and the peak serum ALT (median, 528 vs $784 \mathrm{U} / \mathrm{L}$ ) and $R$ values were lower than those cases with autoimmune features (Table 4). Prolonged cholestasis may also occur, as exemplified by DILIN subject 3 .

The mechanism by which the TNF- $a$ antagonists lead to DILI is unknown. Because the injury can occur after only one infusion, dose-dependent toxicity is unlikely, although patients in whom low dose etanercept was tolerated after developing DILI with full dose injection have been reported. ${ }^{11,12}$ Unpredictable idiosyncratic DILI seems most likely, because in this series no patients had clinical evidence of a rash or eosinophilia, and only one presented with fever. Nonetheless, the serologic and histopathologic studies with features of AIH strongly suggest that humoral and cell-mediated immune responses are important in the pathogenesis. Further studies are needed to ascertain whether genetic or other markers of the hepatotoxicity associated with TNF- $\alpha$ antagonists can be identified.

In summary, we have described 6 well-characterized cases of DILI in the setting of TNF- $a$ antagonist therapy and also reviewed 28 additional published cases. The most common clinical presentation was that of an acute hepatocellular injury with autoimmune features, including histologic changes that are similar to spontaneous AIH. Additional presentations 
include a milder mixed injury pattern with shorter latency and less commonly, a prolonged cholestatic injury pattern. The prognosis is generally favorable, and corticosteroids may be helpful in accelerating resolution in subjects with autoimmune features. Treatment with an alternative TNF- $\alpha$ antagonist after resolution of the liver injury appears to be well tolerated without recurrence.

\section{Supplementary Material}

Refer to Web version on PubMed Central for supplementary material.

\section{Acknowledgments}

Funding

The U.S. Drug Induced Liver Injury Network (DILIN) is supported by the National Institute of Diabetes and Digestive and Kidney Diseases under the following cooperative agreements: 1U01DK065021, U01DK065193, 1U01DK065201, 1U01DK065193, 1U01DK065184, 1U01DK065211, 1U01DK065238, and 1U01DK065176.

\section{Abbreviations used in this paper}

AIH autoimmune hepatitis

$\begin{array}{ll}\text { Alk Phos } & \text { alkaline phosphatase } \\ \text { ALT } & \text { alanine aminotransferase } \\ \text { ANA } & \text { antinuclear antibody } \\ \text { ASMA } & \text { anti-smooth muscle antibody } \\ \text { AST } & \text { aspartate aminotransferase } \\ \text { DILI } & \text { drug-induced liver injury } \\ \text { DILIN } & \text { U.S. Drug-Induced Liver Injury Network } \\ \text { Ig } & \text { immunoglobulin } \\ \text { INR } & \text { international normalized ratio } \\ \text { RUCAM } & \text { Roussel-Uclaf Causality Assessment Method } \\ \text { TNF- } a & \text { tumor necrosis factor- } a\end{array}$

\section{References}

1. Bezabeh S, Flowers C, Kortepeter C, et al. Clinically significant liver injury in patients treated with natalizumab. Aliment Pharmacol Ther. 2010; 31:1028-1035. [PubMed: 20163378]

2. Davern, T. Hepatotoxicity of immunomodulator agents and the transplant situation. In: Kaplowitz, N.; Deleve, L., editors. Drug-induced liver injury. New York: Informa Helathcare; 2007.

3. Carroll MB, Bond MI. Use of tumor necrosis factor-a inhibitors in patients with chronic hepatitis B infection. Semin Arthritis Rheum. 2008; 38:208-217. [PubMed: 18221983]

4. FDA. [Accessed November 2011.] Briefing document: Arthritis Advisory Committee. Available from: http://www.fda.gov/ohrms/dockets/ac/03/transcripts/3930T1.htm

5. García Aparicio A, Rey J, Sanz A, et al. Successful treatment with etanercept in a patient with hepatotoxicity closely related to infliximab. Clin Rheumatol. 2007; 26:811-813. [PubMed: 16550301]

6. Thiéfin G, Morelet A, Heurgué A, et al. Infliximab-induced hepatitis: absence of cross-toxicity with etanercept. Joint Bone Spine. 2008; 75:737-739. [PubMed: 18693125] 
7. Fontana R, Seeff LB, Andrade RJ, et al. Standardization of nomenclature and causality assessment in drug-induced liver injury: summary of a clinical research workshop. Hepatology. 2010; 52:730742. [PubMed: 20564754]

8. Benichou C, Danan G, Flahault A. Causality assessment of adverse reactions to drugs: II-an original model for validation of drug causality assessment methods: case reports with positive rechallenge. J Clin Epidemiol. 1993; 46:1331-1336. [PubMed: 8229111]

9. Becker H, Willeke P, Domschke W, et al. Etanercept tolerance in a patient with previous infliximabinduced hepatitis. Clin Rheumatol. 2008; 27:1597-1598. [PubMed: 18795397]

10. Féau S, Causse X, Corondan A, et al. Acute drug-induced hepatitis during adalimumab and ibuprofen treatment. Gastroenterol Clin Biol. 2010; 34:420-422. [PubMed: 20494537]

11. Iwamoto M, Minota S. Successful treatment with very low-dose etanercept in a patient with etanercept-induced liver dysfunction. Rheumatol Int. 2011; 31:561-562. [PubMed: 20349067]

12. Leak AM, Rincon-Aznar B. Hepatotoxicity associated with etanercept in psoriatic arthritis. J Rheumatol. 2008; 35:2286-2287. [PubMed: 19004062]

13. Menghini V, Arora A. Infliximab-associated reversible cholestatic liver disease. Mayo Clin Proc. 2001; 76:84-86. [PubMed: 11155419]

14. Tobon G, Cañas C, Jaller J, et al. Serious liver disease induced by infliximab. Clin Rheumatol. 2007; 26:578-581. [PubMed: 16547695]

15. Massarotti M, Marasini B. Successful treatment with etanercept of a patient with psoriatic arthritis after adalimumab-related hepatotoxicity. Int J Immunopathol Pharmacol. 2009; 22:547-549. [PubMed: 19505409]

16. Kluger N, Girard C, Guillot B, et al. Efficiency and safety of etanercept after acute hepatitis induced by infliximab for psoriasis. Acta Derm Venereol. 2009; 89:332-334. [PubMed: 19479148]

17. Boetticher N, Peine CJ, Kwo P, et al. A randomized, double-blinded, placebo-controlled multicenter trial of etanercept in the treatment of alcoholic hepatitis. Gastroenterology. 2008; 135:1953-1960. [PubMed: 18848937]

18. Naveau S, Chollet-Martin S, Dharancy S, et al. A double-blind randomized controlled trial of infliximab associated with prednisolone in acute alcoholic hepatitis. Hepatology. 2004; 39:13901397. [PubMed: 15122768]

19. Haennig A, Bonnet D, Thebault S, et al. Infliximab-induced acute hepatitis during Crohn's disease therapy: absence of cross-toxicity with adalimumab. Gastroenterol Clin Biol. 2010; 34:e7-e8. [PubMed: 20189334]

20. Subramaniam K, Chitturi S, Brown M, et al. Infliximab-induced autoimmune hepatitis in Crohn's disease treated with budesonide and mycophenolate. Inflamm Bowel Dis. 2011; 17:E149-E150. [PubMed: 21987301]

21. Sokolove J, Strand V, Greenberg JD, et al. Risk of elevated liver enzymes associated with TNF inhibitor utilisation in patients with rheumatoid arthritis. Ann Rheum Dis. 2010; 69:1612-1617. [PubMed: 20448284]

22. Viganò M, Degasperi E, Aghemo A, et al. Anti-TNF drugs in patients with hepatitis B or C virus infection: safety and clinical management. Expert Opin Biol Ther. 2012; 12:193-207. [PubMed: 22188392]

23. Wahie S, Alexandroff A, Reynolds N. Hepatitis: a rare, but important, complication of infliximab therapy for psoriasis. Clin Exp Dermatol. 2006; 31:460-461. [PubMed: 16681606]

24. De Rycke L, Baeten D, Kruithof E, et al. Infliximab, but not etanercept, induces IgM anti-doublestranded DNA autoantibodies as main antinuclear reactivity: biologic and clinical implications in autoimmune arthritis. Arthritis Rheum. 2005; 52:2192-2201. [PubMed: 15986349]

25. Gonnet-Gracia C, Barnetche T, Richez C, et al. Anti-nuclear antibodies, anti-DNA and C4 complement evolution in rheumatoid arthritis and ankylosing spondylitis treated with TNF-alpha blockers. Clin Exp Rheumatol. 2008; 26:401-407. [PubMed: 18578960]

26. Grasland A, Sterpu R, Boussoukaya S, et al. Autoimmune hepatitis induced by adalimumab with successful switch to abatacept. Eur J Clin Pharmacol. 2012; 68:895-898. [PubMed: 22205272]

27. Adar T, Mizrahi M, Pappo O, et al. Adalimumab-induced autoimmune hepatitis. J Clin Gastroenterol. 2010; 44:e20-e22. [PubMed: 19593165] 
28. Fairhurst DA, Sheehan-Dare R. Autoimmune hepatitis associated with infliximab in a patient with palmoplantar pustular psoriaisis. Clin Exp Dermatol. 2009; 34:421-422. [PubMed: 19309375]

29. Fathalla B, Goldsmith D, Pascasio J, et al. Development of auto-immune hepatitis in a child with systemic-onset juvenile idiopathic arthritis during therapy with etanercept. J Clin Rheumatol. 2008; 14:297-298. [PubMed: 18824922]

30. Germano V, Picchianti Diamanti A, Baccano G, et al. Autoimmune hepatitis associated with infliximab in a patient with psoriatic arthritis. Ann Rheum Dis. 2005; 64:1519-1520. [PubMed: 16162908]

31. Harada K, Akai Y, Koyama S, et al. A case of autoimmune hepatitis exacerbated by the administration of etanercept in the patient with rheumatoid arthritis. Clin Rheumatol. 2008; 27:1063-1066. [PubMed: 18563514]

32. Ozorio G, McGarity B, Bak H, et al. Autoimmune hepatitis following infliximab therapy for ankylosing spondylitis. Med J Aust. 2007; 187:524-526. [PubMed: 17979620]

33. Saleem G, Li S, MacPherson B, et al. Hepatitis with interface inflammation and IgG, IgM, and IgA anti-double-stranded DNA antibodies following infliximab therapy: comment on the article by Charles et al. Arthritis Rheum. 2001; 44:1966-1968. [PubMed: 11508453]

34. Björnsson E, Talwalkar J, Treeprasertsuk S, et al. Drug-induced autoimmune hepatitis: clinical characteristics and prognosis. Hepatology. 2010; 51:2040-2048. [PubMed: 20512992]

35. Mancini S, Amorotti E, Vecchio S, et al. Infliximab-related hepatitis: discussion of a case and review of the literature. Intern Emerg Med. 2010; 5:193-200. [PubMed: 20107930]

36. Carlsen K, Riis L, Madsen O. Toxic hepatitis induced by infliximab in a patient with rheumatoid arthritis with no relapse after switching to etanercept. Clin Rheumatol. 2009; 28:1001-1003. [PubMed: 19370307]

37. Soto-Fernández S, González-Carro P, De Pedro-Esteban A, et al. Infliximab-induced hepatitis in a patient with Crohn's disease. Gastroenterol Hepatol. 2006; 29:321-322. [PubMed: 16733041]

38. Poulin Y, Thérien G. Drug-induced hepatitis and lupus during infliximab treatment for psoriasis: case report and literature review. J Cutan Med Surg. 2010; 14:100-104. [PubMed: 20338127]

39. Marques M, Magro F, Cardoso H, et al. Infliximab-induced lupus-like syndrome associated with autoimmune hepatitis. Inflamm Bowel Dis. 2008; 14:723-725. [PubMed: 17929297]

40. Ierardi E, Valle ND, Nacchiero MC, et al. Onset of liver damage after a single administration of infliximab in a patient with refractory ulcerative colitis. Clin Drug Invest. 2006; 26:673-676.

41. Goujon C, Dahel K, Bérard F, et al. Autoimmune hepatitis in two psoriasis patients treated with inflixmab. J Am Acad Dermatol. 2010; 63:e43-e44. [PubMed: 20633783]

42. Doyle A, Forbes G, Kontorinis N. Autoimmune hepatitis during infliximab therapy for Crohn's disease: a case report. J Crohns Colitis. 2011; 5:253-255. [PubMed: 21575891]

43. Moum B, Konopski Z, Tufteland K, et al. Occurrence of hepatoxicicty and elevated liver enzymes in a Crohn's disease patient treated with infliximab. Inflamm Bowel Dis. 2007; 13:1584-1586. [PubMed: 17663423]

44. Cravo M, Silva R, Serrano M. Autoimmune hepatitis induced by infliximab in a patient with Crohn's disease with no relapse after switching to adalimumab. BioDrugs. 2010; 24(Suppl 1):2527. [PubMed: 21175232]

45. Goldfeld D, Verna E, Lefkowitch J, et al. Infliximab-induced auto-immune hepatitis with successful switch to adalimumab in a patient with Crohn's disease: the index case. Dig Dis Sci. 2011; 56:3386-3388. [PubMed: 21597977] 

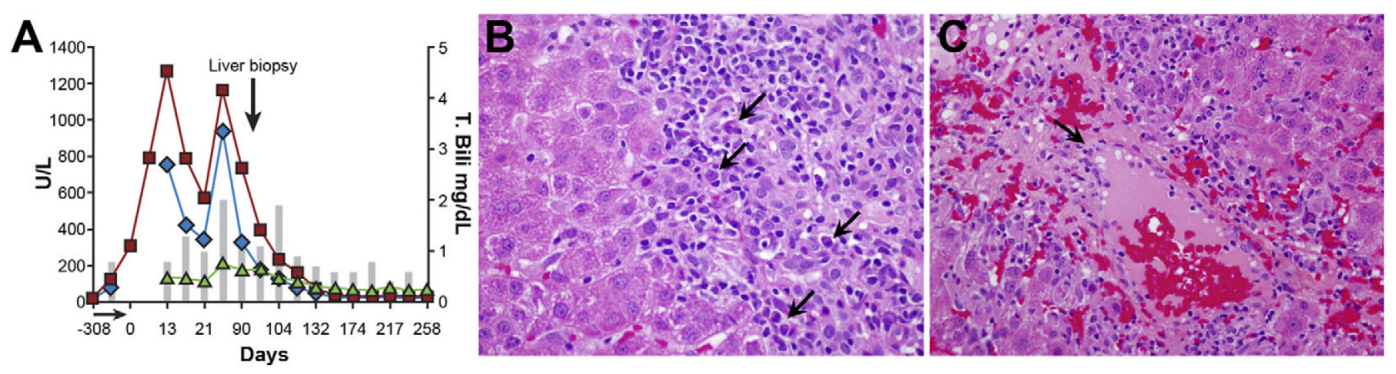

Figure 1.

DILIN subject 1. (A) Graphic summary of DILI caused by infliximab. Left vertical axis, serum enzymes (U/L); right vertical axis, serum total bilirubin (mg/dL); horizontal axis, time in days, with onset of DILI being day 0. Blue diamonds, serum AST; red squares, serum ALT; green triangles, serum Alk Phos; gray columns, serum total bilirubin; horizontal red arrow, duration of treatment with the anti-TNF-agent; vertical blue arrow, timing of liver biopsy. (B) Marked interface hepatitis with plasma cells (arrows) (H\&E; original magnification, $\times 600)$. (C) Zone 3 necrosis with inflammation and venulitis (arrow) (H\&E; original magnification, $\times 400)$. 
Table 1

Presenting Clinical and Laboratory Features of 6 DILIN Subjects With Liver Injury Attributed to Anti-TNF-a Agents

\begin{tabular}{lc}
\hline Clinical parameter & Subjects with DILI caused by anti-TNF-a agents $(\mathbf{n}=6)$ \\
\hline Median age, $y(25 \%-75 \%)$ & $35(33-38)$ \\
Female sex & $5(83 \%)$ \\
Body mass index $\left(\mathrm{kg} / \mathrm{m}^{2}\right)$ & $27(20-44)$ \\
Latency $(w k s)$ & $16(2-52)$ \\
Peak ALT $(U / L)$ & $914(384-1687)$ \\
Peak Alk Phos $(U / L)$ & $202(83-1311)$ \\
Peak total bilirubin $(m g / d L)$ & $9.8(1.5-34.2)$ \\
Peak INR & $1.3(1-3.5)$ \\
$R$ value & $10(3-25)$ \\
\hline
\end{tabular}

$R$ value, ratio of (serum ALT/upper limit of normal for ALT) divided by (Alk Phos/upper limit of normal for Alk Phos). 
Table 2

Summary of the 6 DILIN Cases and 28 Previously Published Cases of DILI Attributed to Anti-TNF-a Agents

\begin{tabular}{|c|c|c|c|c|}
\hline $\begin{array}{l}\text { Anti-TNF- } \alpha \text { agent and DILIN case number or } \\
\text { reference citation }\end{array}$ & Age $(y)$, sex & Disease & Dose & $\begin{array}{l}\text { Duration of therapy before } \\
\text { onset of DILI (wks) }\end{array}$ \\
\hline Infliximab DILIN 1 & $28, \mathrm{M}$ & $\mathrm{CD}$ & $5 \mathrm{mg} / \mathrm{kg}$ & 20 \\
\hline Infliximab DILIN 2 & $54, \mathrm{~F}$ & PsA & $5 \mathrm{mg} / \mathrm{kg}$ & 12 \\
\hline Infliximab DILIN 3 & $35, \mathrm{~F}$ & CUC & $5 \mathrm{mg} / \mathrm{kg}$ & 2 \\
\hline Etanercept DILIN 4 & $34, \mathrm{~F}$ & Ps & $50 \mathrm{mg}$ & 15 \\
\hline Etanercept DILIN 5 & $35, \mathrm{~F}$ & Ps & $25 \mathrm{mg}$ twice per week & 16 \\
\hline Adalimumab DILIN 6 & $33, \mathrm{~F}$ & $\mathrm{CD}$ & $40 \mathrm{mg}$ & 52 \\
\hline Infliximab $^{5}$ & $48, \mathrm{M}$ & AS & $5 \mathrm{mg} / \mathrm{kg}$ & 14 \\
\hline Infliximab $^{6}$ & $48, \mathrm{M}$ & AS & $5 \mathrm{mg} / \mathrm{kg}$ & 36 \\
\hline Infliximab $^{16}$ & $46, \mathrm{~F}$ & PsA & $5 \mathrm{mg} / \mathrm{kg}$ & 22 \\
\hline Infliximab $^{28}$ & $22, \mathrm{~F}$ & Ps & $5 \mathrm{mg} / \mathrm{kg}$ & 6 \\
\hline Infliximab $^{32}$ & $54, \mathrm{~F}$ & AS & $5 \mathrm{mg} / \mathrm{kg}$ & 12 \\
\hline Infliximab $^{35}$ & $33, \mathrm{M}$ & Ps & NA & 20 \\
\hline Infliximab $^{36}$ & $38, \mathrm{~F}$ & RA & $3 \mathrm{mg} / \mathrm{kg}$ & 38 \\
\hline Infliximab $^{37}$ & $43, \mathrm{~F}$ & $\mathrm{CD}$ & $5 \mathrm{mg} / \mathrm{kg}$ & 4 \\
\hline Infliximab $^{38}$ & $40, \mathrm{~F}$ & PsA & $5 \mathrm{mg} / \mathrm{kg}$ & 22 \\
\hline Infliximab $^{23}$ & $64, \mathrm{M}$ & Ps & $5 \mathrm{mg} / \mathrm{kg}$ & 3 \\
\hline Infliximab $^{30}$ & $53, \mathrm{~F}$ & PsA & $3 \mathrm{mg} / \mathrm{kg}$ & 30 \\
\hline Infliximab $^{33}$ & $36, \mathrm{~F}$ & RA & $3 \mathrm{mg} / \mathrm{kg}$ & 12 \\
\hline Infliximab $^{39}$ & $34, \mathrm{~F}$ & CUC & $5 \mathrm{mg} / \mathrm{kg}$ every 2 weeks & 16 \\
\hline Infliximab $^{40}$ & $28, \mathrm{M}$ & CUC & $5 \mathrm{mg} / \mathrm{kg}$ & 1.5 \\
\hline Infliximab $^{14}$ & $39, \mathrm{~F}$ & RA & $3 \mathrm{mg} / \mathrm{kg}$ & 32 \\
\hline Infliximab, case $1^{41}$ & $37, \mathrm{M}$ & Ps & $5 \mathrm{mg} / \mathrm{kg}$ & 12 \\
\hline Infliximab, case $2^{41}$ & $51, \mathrm{M}$ & Ps & $5 \mathrm{mg} / \mathrm{kg}$ & 10 \\
\hline Infliximab $^{42}$ & $60, \mathrm{M}$ & $\mathrm{CD}$ & $5 \mathrm{mg} / \mathrm{kg}$ & 14 \\
\hline Infliximab $^{19}$ & $46, \mathrm{M}$ & $\mathrm{CD}$ & $5 \mathrm{mg} / \mathrm{kg}$ & 6 \\
\hline Infliximab $^{43}$ & $45, \mathrm{~F}$ & $\mathrm{CD}$ & $5 \mathrm{mg} / \mathrm{kg}$ & 7 \\
\hline Infliximab $^{44}$ & $38, \mathrm{~F}$ & $\mathrm{CD}$ & $5-10 \mathrm{mg} / \mathrm{kg}$ & 104 \\
\hline Infliximab $^{20}$ & $33, \mathrm{M}$ & $\mathrm{CD}$ & NA & 20 \\
\hline Infliximab $^{45}$ & $58, \mathrm{~F}$ & $\mathrm{CD}$ & $5 \mathrm{mg} / \mathrm{kg}$ & 12 \\
\hline Etanercept $t^{31}$ & $50, \mathrm{~F}$ & RA & $25 \mathrm{mg}$ twice per week & 2 \\
\hline Etanercept ${ }^{29}$ & $9, \mathrm{~F}$ & JIA & $0.4 \mathrm{mg} / \mathrm{kg}$ twice per week & 40 \\
\hline Adalimumab $^{27}$ & $36, \mathrm{~F}$ & PsA & $40 \mathrm{mg}$ every other week & 12 \\
\hline Adalimumab $^{15}$ & $46, \mathrm{M}$ & PsA & $40 \mathrm{mg}$ every other week & 12 \\
\hline Adalimumab $^{26}$ & $35, \mathrm{~F}$ & RA & NA & 5 \\
\hline
\end{tabular}

NOTE. Adalimumab was administered every other week. Infliximab was administered at 0,2 , and 6 weeks and every 8 weeks thereafter. Etanercept was administered weekly or twice weekly, as shown.

AS, ankylosing spondylitis; CD, Crohn's disease; CUC, chronic ulcerative colitis; JIA, juvenile inflammatory arthritis; NA, not available; Ps, psoriasis; PsA, psoriatic arthritis; RA, rheumatoid arthritis. 


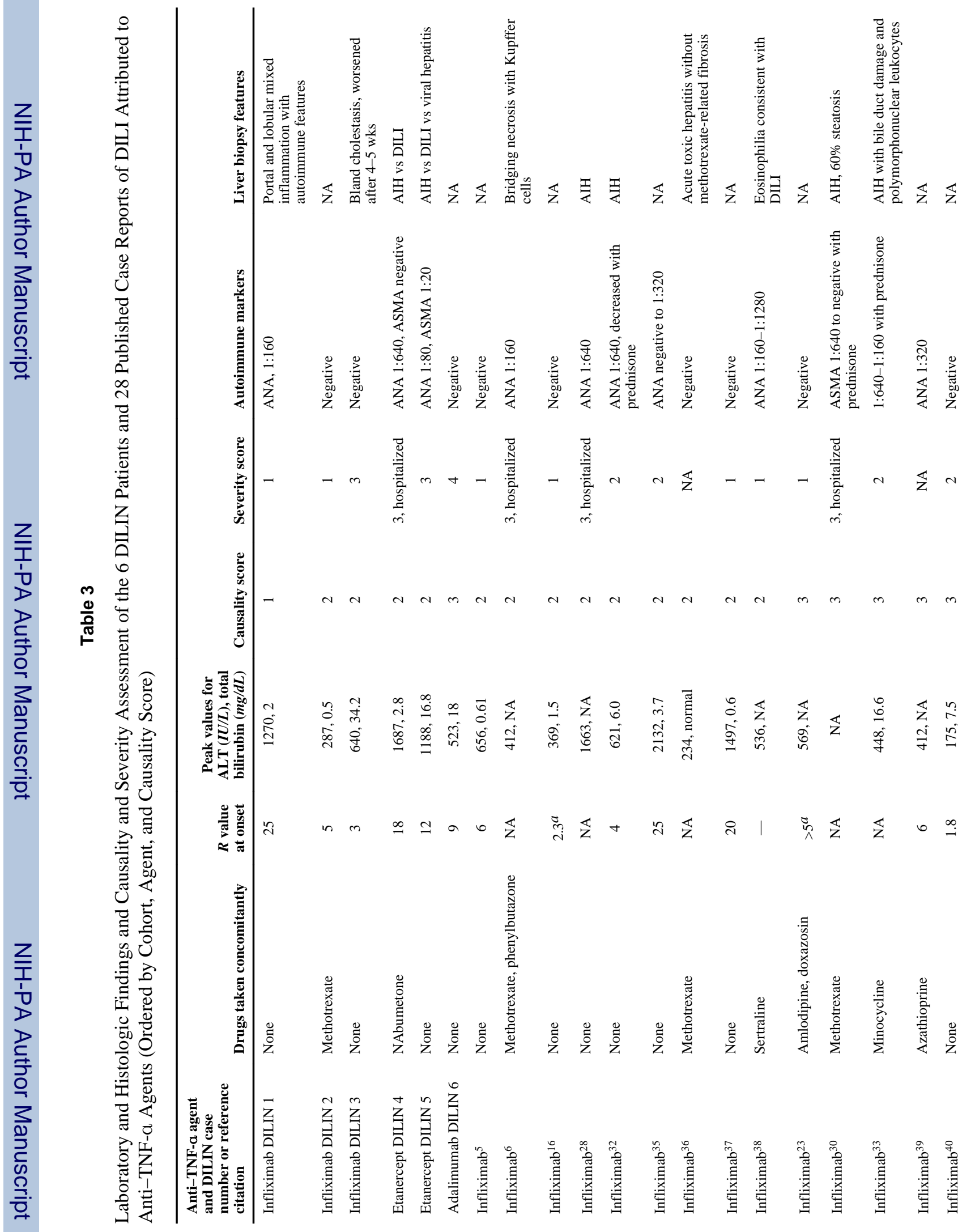


GHABRIL et al.

Page 14

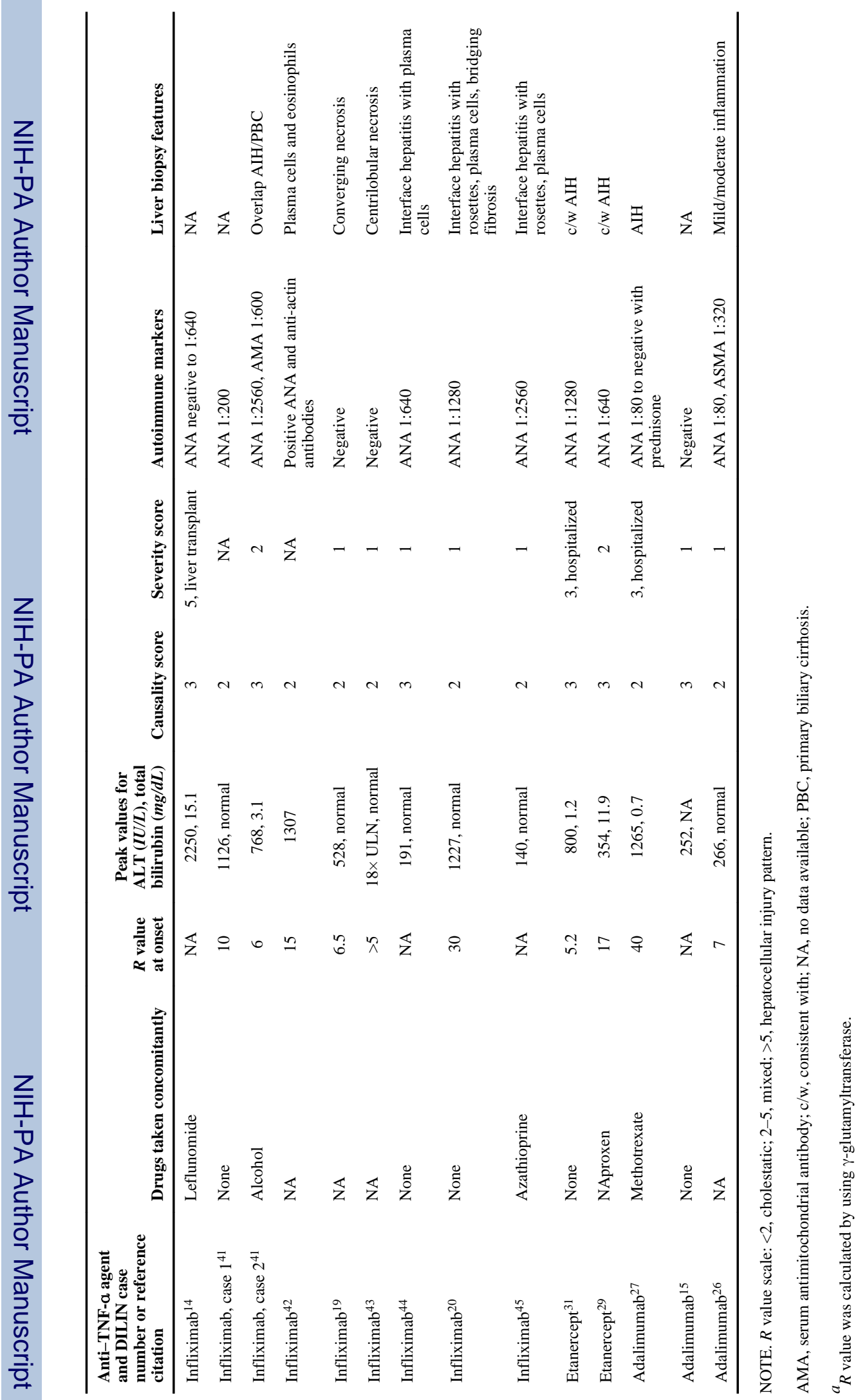

Clin Gastroenterol Hepatol. Author manuscript; available in PMC 2014 May 01. 
Table 4

Comparison of Subjects With Autoimmune Features With Subjects Without

\begin{tabular}{lccc}
\hline Clinical parameter & With autoimmune features $(\mathbf{n = 2 2})$ & Without autoimmune features $(\mathbf{n}=12)$ & $P$ value \\
\hline Latency $(w k)^{a}$ & $16(2-104)$ & $10(2-52)$ & .17 \\
Peak ALT $(U / L)^{a}$ & $784(140-2250)$ & $528(175-2491)$ & .03 \\
Peak bilirubin $(m g / d L)^{a}$ & $2.4(0.7-16.8)$ & $1.0(0.6-27.7)$ & .9 \\
$R$ value & $13(4-40)$ & $6(1.8-20)$ & .01 \\
\hline
\end{tabular}

${ }^{a}$ Values are described as medians and (ranges). 